\title{
Current Challenges of Medical Translation - międzynarodowa konferencja i warsztaty w ramach Translating Europe Workshop, Gdańsk, 18.05.2017 (sprawozdanie)
}

DOI: http://dx.doi.org/10.12775/RP.2017.025

18 maja 2017 roku w Gdańsku na Wydziale Filologicznym miała miejsce międzynarodowa konferencja Current Challenges of Medical Translation. Jednocześnie odbyły się też warsztaty poświęcone problemom przekładu medycznego - oba wydarzenia zostały zorganizowane w ramach programu Translating Europe Workshop. Organizatorem konferencji jest Centrum Translatoryczne (pod kierownictwem dr hab. Olgi Kubińskiej, prof. UG, którą wsparli dr Wioleta Karwacka oraz mgr Maciej Kur) we współpracy z Przedstawicielstwem Dyrekcji Generalnej ds. Tłumaczeń Pisemnych (reprezentowanej przez p. Jacka Wasika).

Konferencja w założeniu odnosiła się do takich praktycznych aspektów przekładu medycznego, jak: jakość, zarządzanie projektem czy przestrzeganie obowiązujących w branży konwencji, a także terminologia medyczna, metody wykorzystywane do jej zarządzania i normowania za pomocą ujednoliconych leksykonów, baz danych i innych narzędzi. Jej głównymi adresatami byli pracownicy naukowi, tłumacze, doktoranci i studenci studiów translatorycznych. Dodatkową zaletą i zarazem przejawem innowacyjności było stałe łącze wideokonferencyjne z trzema ośrodkami akademickimi, czyli Uniwersytetem Jagiellońskim w Krakowie, Uniwersytetem Mikołaja Kopernika w Toruniu oraz Uniwersytetem Warmińsko-Mazurskim w Olsztynie. Osoby zainteresowane uczestnictwem w konferencji lub warsztatach miały możliwość zarejestrowania się na stronie konferencji, a następnie otrzymania certyfikatów udziału. Dzięki łączeniu wideo wszystkie ośrodki mogły nie tylko widzieć i słyszeć prelegentów oraz przygotowane prezentacje, ale również uczestniczyć w dyskusji. Na samą konferencję zarejestrowało się ponad 200 osób ze wszystkich ośrodków, co tylko potwierdza bardzo duże zainteresowanie tematyką konferencji i potrzebę poszerzania wiedzy w tej dziedzinie. Językiem konferencyjnym był język angielski.

Konferencja została podzielona na trzy części: pierwsza obejmowała cztery wykłady plenarne, część druga to wykłady w dwóch równoległych sekcjach, natomiast część trzecia to praktyczne warsztaty prowadzone przez cze- 
rech wykładowców. W sprawozdaniu przedstawię w skrócie główne tematy poruszone w wystąpieniach plenarnych oraz w sekcjach.

Morten Pilegaard z Uniwersytetu Aarhus w swoim wystąpieniu „Seizing the middle ground between translation and copyediting. Towards a new role for the medical translator? An auto-ethnographic perspective on the translation of medical research articles" przedstawił podejście autoetnograficzne do przekładu, którego skutkiem jest nowa rola tłumacza jako mediatora specjalistycznej wiedzy. To z kolei ma wpływ na warunki pracy tłumacza i pozwala mu na analizę nowych możliwości w działalności tłumaczeniowej w interakcji funkcji, procesu przekładu i produktów tego procesu. Hannelore Lee-Jahnke (Uniwersytet Genewski) w prezentacji „Training in Medical Translation: why, when, where \& how" odniosła się do znaczenia przekładu medycznego w bieżących warunkach geopolitycznych. Podkreśliła, że w rzeczywistości akademickiej należy zadać sobie pytanie co do etapu edukacyjnego, na którym kształcenie przyszłych tłumaczy w dziedzinie przekładu medycznego powinno być realizowane, a także jaką formę ma przybrać (np. studia magisterskie, kształcenie ustawiczne czy też szkolenie studentów medycyny w warunkach szpitalnych). Božena Džuganová (Uniwersytet Komeńskiego w Bratysławie) w wystąpieniu zatytułowanym „Some Aspects of Medical English Some aspects of medical English terminology" zauważyła, że w terminologii medycznej można zaobserwować dwa odmienne zjawiska, a mianowicie 1) występowanie mianownictwa anatomicznego, które jest dokładnie i precyzyjnie opracowane i ustandaryzowane w skali międzynarodowej oraz 2) dynamicznie rozwijającą się nieustandaryzowaną terminologię obowiązującą $\mathrm{w}$ poszczególnych dziedzinach klinicznych z typowym dla niej terminologicznym chaosem. Vicent Montalt z Universitat Jaume I (Hiszpania) odniósł się w swoim referacie „Patient-centred translation in focus - challenges and opportunities" do relatywnie nowej dziedziny, jaką jest medycyna spersonalizowana i opieka medyczna zorientowana na pacjenta, a także do ich wpływu na redefinicję komunikacji w opiece zdrowotnej w warunkach świata opartego na wielokulturowości i wielojęzyczności. Montalt zauważa, że tłumaczenie dla pacjenta powoli staje się niezwykle istotną częścią przekładu medycznego w ogóle, co pociąga za sobą konieczność zmiany pewnych schematów koncepcyjnych i ram definicyjnych.

W części panelowej konferencji wystąpiło sześciu mówców: Radosław Mackiewicz z firmy Skrivanek Polska omówił kwestie związane z zarządzaniem projektem i zapewnieniem jakości w tłumaczeniu tekstów medycznych. Arkadiusz Badziński (Uniwersytet Śląski) przedstawił swoje obserwa- 
cje i wnioski dotyczące tłumaczenia symultanicznego tekstów medycznych. Zaakcentował poważne konsekwencje błędów w tłumaczeniu, a także znaczenie funkcjonalnej synonimiczności terminów medycznych. Ewa Kujawska-Lis (Uniwersytet Warmińsko-Mazurski w Olsztynie) podkreśliła, że w zależności od założonego skopos tłumacz może stosować różną terminologię (rejestry), co zresztą wynika z dynamiki zmian języka. Ewa Kościałkowska-Okońska (Uniwersytet Mikołaja Kopernika w Toruniu) przedstawiła analizę stosowanego w ulotkach lekowych języka, który powinien stosować się do zasad użyteczności i być w efektywny komunikacyjnie sposób dostosowany do potrzeb konkretnych grup użytkowników (lekarzy, pracowników ochrony zdrowia i pacjentów). Magdalena Bielenia-Grajewska (Uniwersytet Gdański) omówiła w swojej prezentacji zjawisko medycyny narracyjnej i jej znaczenia w komunikacji medycznej w oparciu o narrację pacjentów onkologicznych (na przykładach artykułów, literatury czy też stron internetowych lub blogów). Ana Muñoz (Miquel Universitat w Walencji) oraz Paula Saiz-Hontangas (Universitat Jaume I, Castello de la Plana) we wspólnym wystąpieniu przedstawily analizę studium przypadku oraz strategie zastosowane w celu udoskonalenia zarówno rozwiązań natury technicznej (kwestie typograficzne, umieszczanie zdjęć itp.), jak i czytelności przekładu (dodawanie i pomijanie informacji, przeformułowanie i rekontekstualizacja określonych terminów specjalistycznych). W założeniu strategie te mają mieć implikacje dydaktyczne.

Końcowym elementem konferencji były cztery warsztaty dla studentów obejmujące różne zagadnienia związane z przekładem medycznym i poświęcone następującym kwestiom:

- O wzlotach i upadkach w życiu tłumacza medycznego (Paweł Baka);

- Tłumaczenie polskich kart informacyjnych leczenia szpitalnego na język angielski (Małgorzata Kasprowicz);

- Znajomość języka czy znajomość dziedziny: o zmaganiach tłumaczy przysięgłych (Ewa Kościałkowska-Okońska);

- Tłumaczenia medyczne - niełatwe lecz fascynujące (Paulina Liedtke).

Szeroki zakres tematyczny i ważkość kwestii poruszanych w trakcie wystąpień plenarnych, panelowych i warsztatów wzbudziły żywe dyskusje wśród uczestników, a dzięki możliwości zadawania pytań autorom - również w trybie wideokonferencji - mogliśmy uczestniczyć w ożywionej wymianie zdań, poruszającej istotne tematy i odbywającej się w życzliwej i pełnej zrozumienia atmosferze. Liczna obecność uczestników, wśród których znalazło się wielu adeptów sztuki przekładu, pokazuje, jak potrzebne są takie spotkania i jak mocno odczuwalny jest ich brak na krajowej arenie konferencyjnej. 
Nawiązywaniu kontaktów oraz kontynuacji dyskusji poza ograniczeniami sal konferencyjnych sprzyjała uroczysta kolacja w restauracji w Pałacu Opatów w otoczeniu pięknego Parku Oliwskiego.

Należy żywić nadzieję, że ta cenna inicjatywa konsolidująca środowisko naukowców, tłumaczy tekstów medycznych oraz adeptów sztuki przekładu znajdzie kontynuację już w niedalekiej przyszłości.

Ewa Kościałkowska-Okońska ewako@umk.pl (Uniwersytet Mikołaja Kopernika w Toruniu)

(c) $(1) \Theta$ 